\title{
Land Administration and Cadastral Trends - A Framework for Re-Engineering
}

\author{
Ian Williamson \\ Professor of Surveying and Land Information \\ Department of Geomatics \\ The University of Melbourne \\ Parkville, Victoria 3010, Australia \\ Tel: + 61-3- 8344 4431; Fax: + 61-3-9347 4128 \\ Email: i.williamson@eng.unimelb.edu.au \\ URL: www.geom.unimelb.edu.au/people/ipw.html \\ Lisa Ting \\ PhD candidate \\ Department of Geomatics \\ The University of Melbourne \\ Parkville, Victoria 3052, Australia \\ Tel: + 61-3- 8344 9696; Fax: + 61-3-9347 2916 \\ Email: ting@sunrise.sli.unimelb.edu.au
}

\begin{abstract}
This paper reviews the need for a new land administration vision that takes a more integrated approach rather than the historic fragmented approach and examines change management of land administration and cadastral systems in the context of global drivers of change. This results in the development of a framework for re-engineering land administration systems. After discussing a land administration vision the paper reviews trends and issues in the context of this framework. While the paper discusses global issues and trends, the paper concentrates on the experiences and ongoing land administration research of the authors' and their colleagues with a focus on Australia.
\end{abstract}

\section{INTRODUCTION}

Global drivers such as sustainable development, globalisation, urbanisation, economic reform and technology are changing the way humankind relates to land [27]. This changing relationship requires new land administration infrastructures and tools. As a result, existing land administration and cadastral systems are being re-engineered. This paper builds on this scenario to consider a new vision for land administration and develops a framework for reengineering future land administration systems to achieve the vision.

Initially the paper describes the new world order which is driving the reform and reengineering of many land administration systems. The paper then reviews some of the key cadastral and land administration initiatives and publications over the last 50 years which led to the recent United Nations (UN) - International Federation of Surveyors (FIG) Bathurst Declaration on Land Administration for Sustainable Development [34, 53]. The land administration and cadastral reform process is then reviewed and leads into a discussion on the need for and form of land administration visions. Some of the trends and issues concerned with moving to a new land administration vision, which have been highlighted by land administration agencies in Australia and are the subject of research by the authors' colleagues, are discussed. However it is acknowledged that these are only some of the land administration issues being addressed world-wide, although they are representative of many 
current issues and trends. The paper concludes with an argument to take a more holistic approach to land administration reform.

Central to this paper is the over-riding principle that land administration and cadastral systems are a key component of the infrastructure that supports and facilitates the way that society interacts with land to ensure sustainable development.

\section{A NEW WORLD ORDER}

The global drivers of sustainable development, globalisation, urbanisation, economic reform and technology influence the development of the different land administration polices and models adopted by governments. These models and concepts can only be developed with a clear understanding of current land administration issues and trends. By its very nature, land administration focuses on land tenure and cadastral (land parcel related) issues. The land administration perspective includes understanding the changing humankind-land relationship, land tenure issues such as native title, institutional and administrative issues such as the relationship between infrastructures and the business systems they support, and technical issues such as those concerned with the use of the World Wide Web (WWW).

A review of the dynamic humankind-land relationship [28] shows that in a western context, it may be classified into four broad phases:

1. Human settlement during the agricultural revolution through to the feudal system, which tied human beings to land in a physical way. Land was the primary symbol and source of wealth. In this phase, the cadastral system's role was to publicly record ownership as well as for fiscal purposes.

2. The Industrial Revolution began a process of breaking that strong physical tie to land by turning land into more of a commodity, albeit the most valuable commodity and primary source of capital. This environment gave birth to land markets and so cadastre took on another focus - a tool to support land transfer and land markets.

3. The post-World War II reconstruction and the population boom saw an awareness of land as a scarce resource that was not sufficient for the needs of a growing world population which was becoming more mobile. With this came an interest in planning, particularly urban and regional planning. Planning in turn created another application for the cadastre.

4. The 1980s have seen a different twist in the concern for the scarcity of land. The focus has turned to wider issues of environmental degradation and sustainable development, as well as social equity. All of these issues have the probable effect of tempering short-term economic imperatives. Planning issues have widened to include more community interests and deepened to address more detailed issues of land use. This has created a growing need for more complex information about land and land use. The impact of these has been manifested in the desire for multi-purpose cadastres.

The key outcome from this analysis is that the relationship of humankind to land in all societies is dynamic and is influenced by these global drivers. 
Sustainable development, as exemplified by the internationally acclaimed instrument Agenda 21 [35], brings environmental issues and social forces such as indigenous and women's rights into the realm of influence alongside and often in opposition to, traditional economic considerations. It is this dynamic which starts to bring land administration and land management into closer and even overlapping proximity. Sustainable development is also linked to globalization. The globalization of markets has led to some controversy. For example, more than a hundred countries agreed at "The Special Session of Governing Council - Global Environmental Forum 2000" (29-31 May, Malmo, Sweden) (organised and sponsored by UNEP), that globalisation has a negative impact on environment and sustainable development. As globalisation is a fact of our times, the challenge is to determine how globalisation can work better for sustainable development. Globalisation has also influenced economic reform such as the radical down-scaling of government, privatisation of services and some policy functions, and the introduction of a competition and serviceoriented philosophy into the remaining government activities.

These tensions emphasise the need for complex and sophisticated decision-making which, in the context of economic reforms, means not only in government but the private sector and wider community. Civil society demands a place in the framework of decision-making. The WWW is just one example of the information revolution potential that exists to bring consultation and participation to a new level of effectiveness.

Many developed countries are in the course of making the transition from the third to the fourth phases, while many developing countries are experiencing change across all four phases. Apart from examining local, state or national legal, institutional, economic and social frameworks, the current era requires that nations take into consideration these global drivers. However for most countries, land administration reform is not that simple. On the one hand the relationship of humankind to land varies across a nation from urban areas, with active land markets and often informal settlements, to both titled and non titled rural areas, to areas under traditional or indigenous rights with no market, to areas under a range of different common property tenures. This then requires different land administration responses for these respective areas [36]. This is further complicated since countries are at different stages of development thereby affecting the choice of the land administration response. As mentioned above neither of these situations is static; neither the different humankind to land relationships nor the stage of development of the country. So the response proposed today based on current requirements may not be appropriate for tomorrow since the requirements may be different.

It is in the context of this new world order that the next generation of land administration systems will have to be developed. This new order lays the foundations and sets the parameters for these new systems which have to be much broader and integrated than the approaches of the past. It is important therefore that we design land administration systems for this future scenario.

\section{TOWARDS THE BATHURST DECLARATION}

The UN-FIG Bathurst Declaration on Land Administration for Sustainable Development $[34,53]$, which resulted from a Workshop and International Conference on Land tenure and Cadastral Infrastructures for Sustainable Development, established a strong linkage between land administration and sustainable development. Importantly this Declaration sets out evolving concepts and principles which add to and build on a rich body of knowledge in 
cadastres and land administration developed over more than half a century. This body of knowledge includes a wide range of journal articles, books, reports, statements, policies and declarations from international organisations such as the UN and the World Bank, from individual country governments, as well as from many individuals. Some of the key institutions active in the area and some important publications include:

1. Reports from the Land Tenure Service of the UN Food and Agriculture Organisation (UNFAO) from as early as 1953 with the publication of the classic publication titled "Cadastral surveys and records of rights in land" by Sir Bernard O. Binns [38] and revised by P.F.Dale in 1995. Also the UN Centre for Human Settlements has been particularly active in land issues over the last decade or so. See www.unchs.org/unchs/land/land.htm.

2. The World Bank has been active in land policy, land reform, land titling and land administration for almost 30 years. A review of the World Bank's land policy for the last 25 years can be seen in Deininger and Binswanger [52]. Numerous other publications have been produced by individuals such as Feder [50], Holstein [49] and Byamugisha [51]. See the World Bank's Land Policy Network at www.worldbank.org/landpolicy for an extensive list of activities and publications.

3. The International Federation of Surveyors has been active in promoting discussion on cadastral and land management issues for almost 100 years. In recent times Commission 7 (Cadastre and Land Management) of the FIG has produced such publications as the 1995 Statement on the Cadastre [13], the 1996 UN-FIG Bogor Declaration on Cadastral Reform [29], the 1997 report on benchmarking cadastral systems [26], the 1998 CADASTRE 2014 [14,15] and the 1999 UN-FIG Bathurst Declaration [34]. The four yearly FIG congresses are also a rich source of cadastral and land administration papers (see the proceedings of the 1998 Congress for example at Commission 7's www site accessed through http://www.fig.net/. The FIG has sponsored the International Office of Cadastre and Land Records (OICRF) which is supported by the Dutch Government as one of its Permanent Institutions since 1958. It has an extensive list of references and can be accessed at www.oicrf.org.

4. Publications supported by the former British Overseas Service such as "Land Registration" by Dowson and Sheppard in 1956 [39], "Land Law and Registration" by Simpson in 1976 [40] and "Cadastral surveys within the Commonwealth" by Peter Dale in 1976 [44].

5. The proceedings of the United Nations Regional Cartographic Conferences which led to meetings on cadastral surveying and mapping in 1973 [41] and 1985 [42], a meeting on surveying and mapping legislation in 1997 [46] and in particular led to the development of the UN-FIG Bogor Declaration on Cadastral Reform and the UN-FIG Bathurst Declaration on Land administration for Sustainable Development discussed below.

6. The extensive research by the Land Tenure Center at the University of WisconsinMadison which was established in 1962 with a particular focus on the land tenure issues in Central and South America [45].

7. As a result of the changes that occurred in Eastern and Central Europe in the early 1990s with a change from command economies to market economies, the UN Economic Commission for Europe (UNECE) saw the need to establish the Meeting on Officials on Land Administration (MOLA). In 1996 MOLA produced the Land Administration Guidelines [17] as one of its many initiatives. 
8. Various books such as the two by Dale and McLaughlin on "Land Information Management" in 1988 [47] and on "Land Administration" in 1999 [48], and by Larsson on "Land registration and cadastral systems" in 1991 [43].

9. Numerous articles in journals such as The Survey Review (UK), The Australian Surveyor (Australia) and GEOMATICA (Canada).

10. Various research groups, typically in universities, investigating cadastral and land administration issues and related topics, often located in surveying, geomatics, geography or law departments; see for example http://www.geom.unimelb.edu.au/research/SDI research/.

Land administration and cadastral systems are continually evolving as society's attitudes and relationship to land changes as can be seen from the evolution of the topics, principles and theory outlined in the above publications. As this relationship with land becomes more complex in terms of the ever increasing number and form of rights, responsibilities and obligations, our land administration information systems that support decision-making, primarily in support of sustainable development, must also adapt to remain relevant. This evolving perception of cadastral and land administration systems, and particularly the relationship between them and sustainable development, is evident from a review of the publications from the above organisations over the last 50 years. For the first 30 years or so the focus was either on the technical aspects of cadastral surveying and mapping or land reform issues. Much of the literature focussed on individual cadastral or land registration activities. It was not until the mid 1980s that the role of cadastral systems and land information was starting to be better understood in the broader context of land administration. However while there continues to be an active interest in cadastral systems, often related to cadastral surveying and mapping and land registration, there has been an increasing focus in the 1990s on the broader role of land administration which includes land valuation and land use planning and a focus on land markets. The latter part of the 1990s saw a growing recognition of the need for land administration systems to better address sustainable development priorities.

These trends recognised that land administration and cadastral systems can no longer rely on manual processes or traditional structures that supported individual economic or taxation imperatives in the past. Stand alone or isolated approaches that supported individual purposes where data and processes were maintained separately, such as land valuation and land titling, are not sustainable. They are being replaced by multipurpose cadastral systems where information about natural resources, planning, land use, land value and land titles, including Western and indigenous interests and common property rights [54], can be integrated for a range of business purposes. As we move further into the information revolution, a clear vision of what land administration and cadastral systems might look like in a decade or so is becoming more urgent. This led to the development of the Bathurst Declaration are discussed below.

As mentioned, the UN and organisations such as the FIG have for many years undertaken studies to understand and describe cadastral and land administration systems and particularly the cadastral component. The interest in land administration infrastructures has been growing over the last few years as a result of the changes necessitated by the global drivers mentioned above but also because of political circumstances such as the fall of apartheid in southern Africa and the changes from command to market economies in Eastern and Central Europe. A key component in most of these studies has been to develop a new land administration vision for a changing world and to explore the steps required to achieve such a vision. 
As a result of the widening interest in cadastre, the UN Regional Cartographic Conference (UNRCC) for Asia and the Pacific which was held in Beijing in 1994 passed a resolution to organise a joint UN-FIG Inter-Regional Meeting of Experts on Cadastre. The resulting meeting was held in Bogor, Indonesia, in March 1996, the primary objective being "to develop a document setting out the desirable requirements and options for cadastral systems of developing countries in the Asia and Pacific region and to some extent globally". As a result of the success of the Bogor Declaration on Cadastral Reform [29], the FIG presented the Declaration at two subsequent UNRCCs for Asia and the Pacific in Bangkok and for the Americas in New York, in 1997.

While the Bogor Declaration resulted in a valuable contribution to a better understanding of cadastral reform, the delegates to the meeting recognised its relatively narrow focus and acknowledged the lack of representation from a wide range of land related experts. As a result one of the recommendations from the Bangkok UNRCC was to organise by 1999 a global workshop on land rights, responsibilities and restrictions and suitable cadastral structures and systems appropriate to the needs of governments for their sustainable development. This latter meeting was to take a broader view of land administration and would draw on a wide range of experts. Assistance was to be sought from the FIG to organise the meeting. This recommendation resulted in the Bathurst Workshop and Melbourne International Conference on Land Tenure and Cadastral Infrastructures for Sustainable Development jointly organised between the UN and the FIG. The major outcome was the Bathurst Declaration [34, 53]. There was recognition in the 1997 UN resolution that the 1999 initiative would build on the vision, guidelines and policies proposed in the previous UN-FIG Bogor Declaration.

The Bogor Declaration adopted the definition and description of a cadastre as set out in the FIG Statement on the Cadastre 1995. Reference was also made to the two previous UN meetings of cadastral experts (in 1972 and 1985) and the Land Administration Guidelines prepared by the Meeting of Officials on Land Administration of the UNECE in 1996.

A central component of the Bogor Declaration is a cadastral vision of the future. This vision and the supporting guidelines, and cadastral reform options and principles formed a starting point for the development of the Bathurst Declaration. Another input into the development of the vision for a future land administration infrastructure is the FIG report on future cadastral systems "Cadastre 2014" [14, 15].

The Bathurst Workshop reflected the evolution described above and explored humankindland relationships for the next millennium in the context of AGENDA 21 and the emerging global village. It determined a broad vision and a set of guidelines for suitable cadastral structures and systems to support land management and in particular land administration to ensure sustainable development and environmental management. It focused on the legal, technical and institutional infrastructure required to support such a vision. The workshop recognised the trend for formal land tenure systems to move from a focus on ownership to one of land rights, responsibilities and restrictions. [35]

The workshop and conference, and the resulting Bathurst Declaration, are another step in the growing awareness of the importance of land administration and cadastral systems in support of sustainable development. This paper suggests a way forward for land administration systems which can build on the Bathurst Declaration. The paper proposes a model to reengineer land administration systems and then looks at two of the most important phases in 
the process - the development of a land administration vision and implementation issues which draw on the current research of the authors' and their colleagues.

\section{LAND ADMINISTRATION AND CADASTRAL REFORM}

The necessity for change in land administration and cadastral systems is highlighted in many reports and statements and is a growing focus for organisations such as the United Nations, the World Bank and the International Federation of Surveyors. Cadastre 2014 [14,15] describes a new vision for cadastral systems. The MOLA Land Administration Guidelines [17] establish a framework for land administration reform with a focus on Central and Eastern Europe. More importantly land administration and cadastral systems world-wide are currently undergoing a period of major change. The Bogor Declaration [29] argues for change, documents a vision and describes the necessity for re-engineering systems.

The Bathurst Declaration [34] concluded that "most land administration systems today are not adequate to cope with the increasingly complex range of rights, restrictions and responsibilities in relation to land, which are influenced by such factors as water, indigenous land use, noise and pollution" and "governmental information systems will have to continue their present trend to become increasingly open and public ... and governments have an important role as umpire, moderator and purveyor". In short, land information and land administration systems need to be re-engineered and to evolve to face the increasing complexity of the humankind-land relationship. Since many existing land administration systems are still based on a relatively narrow land administration paradigm centred on land registration and cadastral surveying and mapping, a new paradigm is required.

The Declaration acknowledged that the changing humankind-land relationship and society's priorities would require changes in land administration systems [34]:

- to play a role in facilitating and supporting the complex decision making that is integral to sustainable development;

- to embrace the inter-relationship between good governance, civil society and land administration for sustainable development, and the need for accountability and benchmarking/performance indicators;

- to embrace the inter-relationship between good governance, civil society and land administration for sustainable development, and the need for accountability and benchmarking/performance indicators;

- to undertake legal, institutional and technological reforms to fulfil the call for inclusive decision-making and a holistic approach to land, water and other resource allocation/preservation issues;

- to ensure an inter-disciplinary approach to land administration and therefore the responsibility of nations to address the need for appropriate human resource development.

- to evolve beyond traditional cadastral paradigms to embrace fresh understanding of the relationship between land, property and rights and the need for initiatives like decisionsupport systems and spatial data infrastructures;

- to respond creatively to differing needs and desires for tenure systems that could deliver equity, whether to specific disadvantaged groups within or between nations;

- to be expanded in order to provide information for land market activities, for public and private land management and for customary and informal tenures, in order to support sustainable development; 
- to the laws concerned with information in the land registration system which may need to be adapted to current technological developments, for instance, in order to facilitate electronic conveyancing;

- to the statutory survey requirements on the location of pegs, boundaries and parcels to be adapted to more flexible circumstances depending on the character of the information and the use of the information for different purposes; and

- to be re-engineered to accommodate other forms of information which may not be parcel based.

Unfortunately much change in the broad land administration area in many countries focuses on technology and does not take a broad view of land administration reform as identified by Ting and Williamson [27] and as set out above. It is useful to consider three related perspectives in implementing change in land administration. First is an appreciation of the global drivers for change which were mentioned previously. Next is an analysis of the impact of these drivers on the design of land administration systems, and particularly the

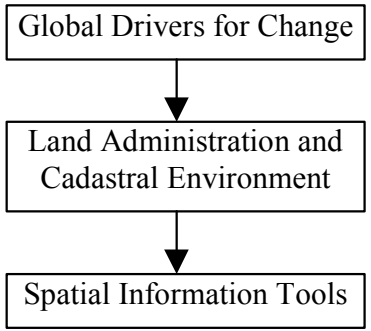

Figure 1. Hierarchy of Perspectives cadastral component, which results in the land administration and cadastral environment from which new systems must evolve. This in turn identifies implementation issues with a focus on technical and administrative tools which support these trends and developments, such as spatial data infrastructures and the Internet. All the changes proposed by the Bathurst Declaration can be categorised into these perspectives and are discussed briefly in this paper. This hierarchy of perspectives is shown in Figure 1. This hierarchy is expanded in the framework for re-engineering land administration systems in Figure 2.

In this framework, global drivers impact on the whole social system which comprises the reengineering process. The framework shows that through a strategic planning process, the vision of a new humankind-land relationship, together with the existing land administration

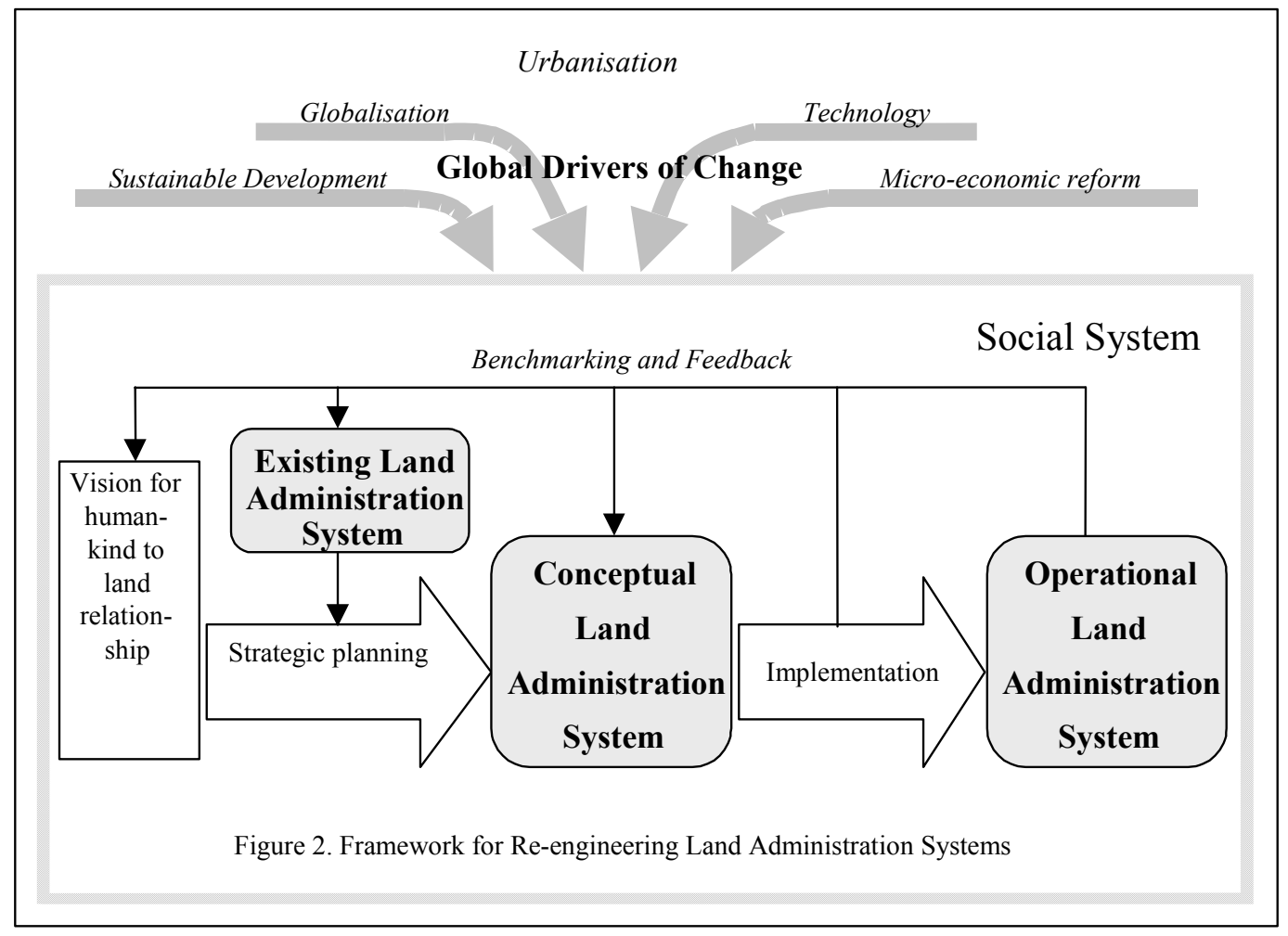


system, results in the development of a conceptual land administration system. Through an implementation process, an operational land administration system is developed. Through benchmarking and feedback, the vision and conceptual system will be continually refined. Some of the key strategic planning and implementation issues within the re-engineering process which are currently being researched by the authors' of this paper and their colleagues and include the spatial dimension of native title, the changing nature of spatial data infrastructures, understanding the business-infrastructure relationship in spatial information management, the use of the WWW and benchmarking processes, are discussed later in the paper.

One of the key steps in the re-engineering process, being the determination of the vision for the humankind-land relationship and the resulting conceptual land administration system, is discussed below.

\section{DEVELOPING A LAND ADMINISTRATION VISION}

The development of a land administration vision for a country is an essential component of any re-engineering process [36]. Land administration reform by its very nature is long term and as such there is a need for a clear road map to ensure that all developments and changes contribute to the overall vision for the land administration system for the country. Due to the complexity of land administration systems there is a strong argument for such projects to comprise "bite size" sub-projects which have a clear focus, however it is essential that these sub-projects are undertaken as part of an agreed vision and global land administration strategy for the country.

Over the years a number of land administration or cadastral models or visions have been developed. Two of the most notable are described in the FIG Statement on the Cadastre [13] and the Bogor Declaration on Cadastral Reform [29]. Cadastre is defined in the Statement on the Cadastre as:

"... normally a parcel based and up-to-date land information system containing a record of interests in land (e.g. rights, restrictions and responsibilities). It usually includes a geometric description of land parcels linked to other records describing the nature of the interests, and ownership or control of those interests, and often the value of the parcel and its improvements. It may be established for fiscal purposes (e.g. valuation and equitable taxation), legal purposes (conveyancing), to assist in the management of land and land use (e.g. for planning and other administrative purposes), and enables sustainable development and environmental protection."

The Bogor Declaration on Cadastral Reform [29] expanded this definition to state that future cadastres would:

"...develop modern cadastral infrastructures that facilitate efficient land and property markets, protect the land rights of all, and support long term sustainable development and land management." And to "...facilitate the planning and development of national cadastral infrastructures so that they may fully service the escalating needs of greatly increased urban populations. These will result from the rapid expansion of cities that is already taking place and which is projected to continue into the 21 st century." 
These visions, as well as the Bathurst Declaration, incorporated the concept of cadastral systems as infrastructures and highlighted the role of cadastres in the operation of land markets. While the Statement on the Cadastre was in reality a definition, the Bogor Declaration was more concerned with strategic and implementation issues, albeit in a relatively narrow cadastral sense.

Williamson [33] developed a 10 year land information management vision for the State of Victoria, Australia to be a central component of any future land administration system. It built on his involvement with the development of the Statement on the Cadastre and the Bogor Declaration in addition to it receiving valuable input from many colleagues worldwide. This vision took a more information systems view of modern land administration and cadastral systems as follows:

"Simply within ten years all tiers of government, the private sector and the wider public will have controlled access to a standardised, complete, nation-wide, current, on-line land information system in real time, which is efficient, economically justified and compatible with other information systems."

A more recent investigation of future cadastral systems is the FIG Cadastre 2014 vision [14, 15]. This was commissioned in 1994 by one of the Working Groups of Commission 7 (Cadastre and Land Management) as a 20 year vision. The final report was the result of a four-year process involving input from many countries worldwide. Cadastre 2014 recognises the changing relationship of humankind to land, the changing role of governments in society, the impact of technology on cadastral reform, the changing role of surveyors in society and the growing role of the private sector in the operation of the cadastre. Cadastre 2014 has made a valuable contribution to the understanding of future cadastral systems. However it did by design restrict its focus to cadastral systems and emphasised technological changes.

These examples of land administration visions show a trend for future land administration and cadastral systems to take a broader and more integrated view than in the past. The components of land registration, cadastral surveying and mapping, planning and land valuation, and their role in the operation of land markets, must all be considered as one integrated system where the common objective is sustainable development. A result of taking such a broad integrated approach is that all rights, restrictions and responsibilities, often overlapping (including both 2 dimensional and 3-dimensional interests), relating to land, must be considered in designing and managing a land administration system as shown in Figure 3. Importantly this includes many more interests than would traditionally be recorded in a cadastral or land registration system. This results in the multi-purpose cadastral concept which has been promoted for the last couple of decades but is only becoming a reality in recent times [68]. Another outcome is the way that land administration is being viewed as an infrastructure to support sustainable development. 


\section{Boundaries of:}

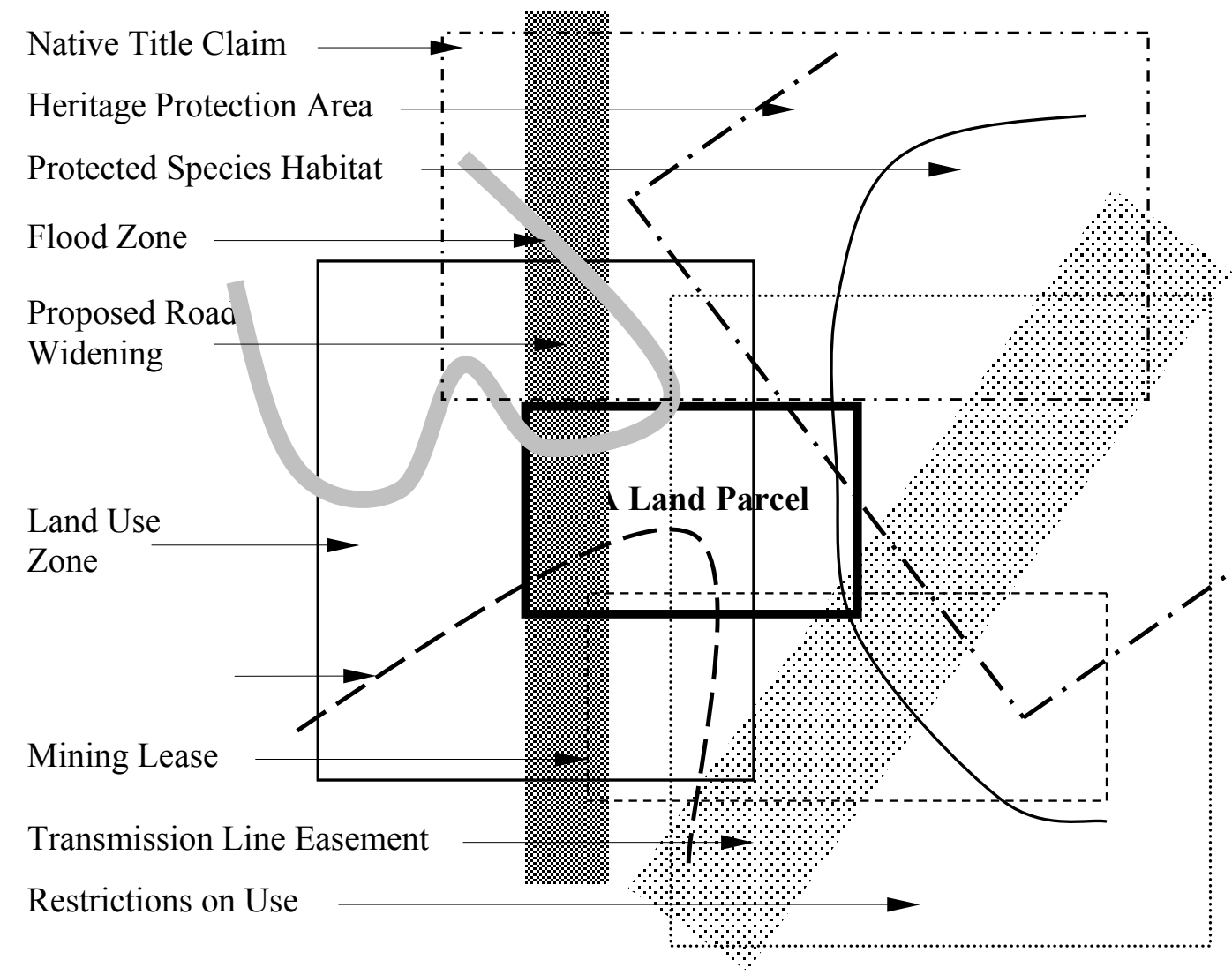

Figure 3: Schematic of overlapping rights, restrictions and responsibilities in a modern multi-purpose cadastre

\section{STRATEGIC AND IMPLEMENTATION ISSUES}

Whether governments are being pushed or pulled towards the above multi-purpose cadastral vision or land administration vision, a move in this direction is almost universal, especially in developed countries. In moving towards this vision, land administration and cadastral systems are being re-engineered as discussed in the framework described in Figure 2. This process highlights a range of strategic and implementation issues which should be considered in developing future land administration systems, although not all will apply to every system. These issues include policy, technical, institutional, administrative and legal components, even though it is often difficult to categorise them as one or another [36]. The influence of these trends and changes are resulting in new rights, restrictions and responsibilities in land, new tenures, new processes and new institutional structures.

New technologies have dictated and influenced many changes in the development of land administration and cadastral systems, especially the information technology advances and the more specialised spatial information technologies. The GIS technologies (such as the Open GIS Consortium (OSG) initiatives [55]) for data management, manipulation, analysis and integration arguably have had the greatest impact on the spatial information environment, 
although in the future the communication technologies such as the WWW and the Wireless Application Protocol (WAP) are rapidly becoming the focus of attention. These technologies are expected to be the norm for viewing, locating and using land related information in the years ahead.

Legislative reform appropriately follows policy development, technological advances and institutional reform and should be a support process in re-engineering land administration systems. Since legislation should be an expression of the implementation of policy adopted at a political level, it is not investigated in this paper, even though its importance in land administration reform is critical [56]. Unfortunately legislation is often used as an excuse to inhibit land administration reform in some countries [30].

Following are some of the land administration and cadastral trends and issues which are part of or influence or result from the re-engineering process that the authors and their colleagues are currently researching. There is no suggestion that these are an exhaustive list but they are representative of current issues. The first issue is concerned with the evolving concept of spatial data infrastructures (SDIs). A discussion of the business-infrastructure relationship is followed by a discussion of the hierarchy of SDIs, the need for partnerships in SDI development, the growing focus on national cadastral data sets in national SDIs and the spatial hierarchy issue. These are then followed by the difficulty of incorporating traditional or customary rights in "western" land administration systems, the complexity of the spatial component of cadastral systems and the impact of the WWW on land administration systems. Lastly issues such as evolving government, professional and educational institutions and benchmarking land administration systems are considered.

\section{Understanding the business-infrastructure relationship in spatial information management}

After studying the growth and utilisation (diffusion) of GIS in state governments [5, 6] Chan [4] details and validates a businessinfrastructure model that can better describe how and why agencies cooperate to develop a GIS (an increasingly important technology within the land administration environment). In this model, a corporate GIS is viewed as comprising inter-related mutuallysupporting multi-leveled modules of business process GIS and infrastructure GIS in the context of the business/production activities of the organisation (Figure 4).

Based on this model, an SDI is disaggregated into a collection of

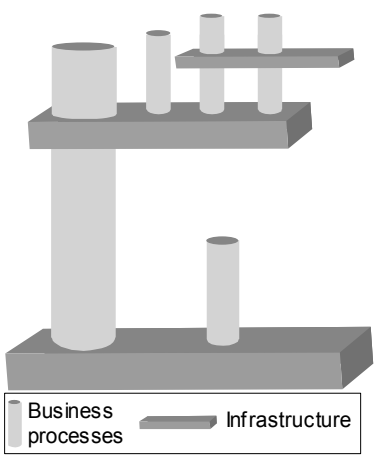
modules of hierarchical infrastructure GIS (the horizontal components). The business process GIS represents the GIS capabilities developed by the users (the vertical components) that rely on the SDI modules to deliver the products and services needed by the geospatial information industry. This GIS may, in turn, nurture the development of new SDI modules, and link different SDI modules together.

The inherent relationships between the infrastructure and the business process in the business-infrastructure model provide a broad framework for any land administration system development. 
Current spatial data infrastructures (SDIs) are in reality a sophisticated version of the systems that most developed nations have had for over 50 years. They are becoming an important component of any land administration infrastructure. Another development is the recognition that SDIs comprise people, a clearinghouse/access network, technical standards, an institutional framework and framework data (typically the geodetic, topographic and hydrology, land parcel or cadastral, road network, administrative boundaries and geographic names layers). The spatial data infrastructures of the past were designed and driven primarily by the providers of the infrastructure. The last decade has seen rapidly expanding numbers of users of spatial data, which are resulting in a proliferation of spatial business systems. These are now influencing and demanding specific characteristics from SDIs. With the rapidly changing spatial information environment and the impact of such technologies as the WWW, GPS, high resolution satellite imagery, communication technologies and sophisticated decision support systems based on GIS technologies, these spatial data infrastructures will continue to change and develop.

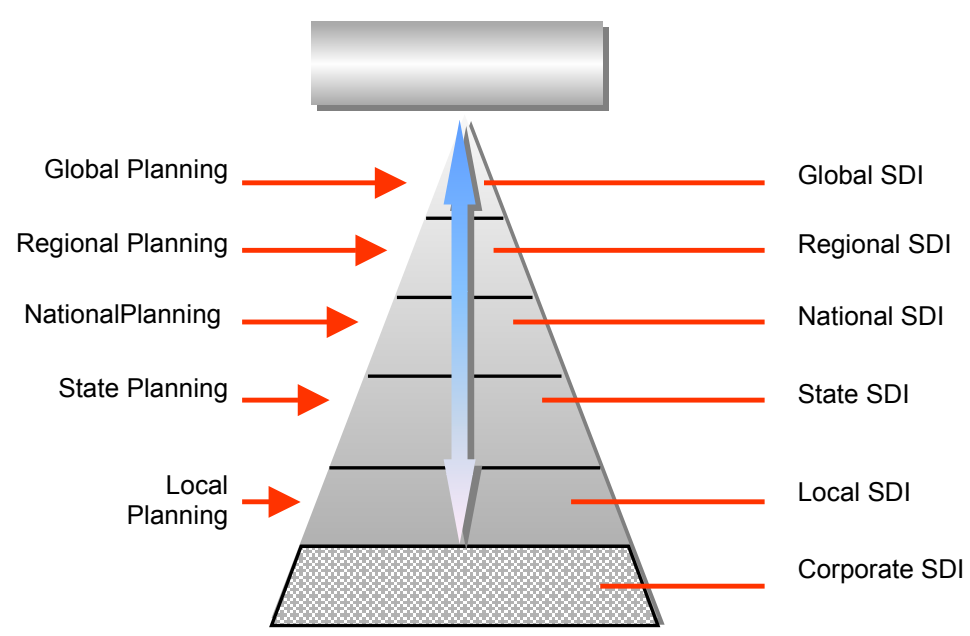

Figure 5

Relationships between data detail, different levels of SDIs, and level of planning $[7,57]$

In exploring such changes it is useful to recognise that SDIs are now often being grouped into a hierarchy (Figure 5) [7, 57] comprising six levels of SDIs, namely, global, regional, national, state (also called provincial), local and corporate. Ideally with compatible sets of SDIs, users working on issues at a higher level in the hierarchy can draw on data from SDIs in all other levels lower in the hierarchy [25]. Again any jurisdiction embarking on the reengineering of land administration systems should take this hierarchical view of SDIs into account. At the same time SDIs are recognised as dynamic systems relying on a complex arrangement of inter- and intra-jurisdictional partnerships (see below).

At the same time there is a growing interest in the relationship between spatial decision support systems, for catchment management as an example, and the future role of SDIs. On the other hand positioning technologies such as satellite positioning, are starting to redefine the SDI concept. Both these areas are important issues for future land administration systems. 


\section{Developing partnerships}

Partnership refers to the association of two or more people as partners in the carrying on of a business with shared risks and profits. In this context it is generally recognised that no one agency can develop a National SDI (NSDI) with the result that different national SDI coordinating agencies are encouraging NSDI development through partnerships [1, 12]. In the USA alone, over 50 major partnership initiatives have been established since 1995 on a thematic, state wide and regional basis. States like Victoria in Australia have recently achieved considerable success in developing strong partnerships with local government in providing the State's SDI. These SDIs, and particularly the cadastral component, are an essential component of future land administration infrastructures.

Australia has accumulated significant experience with the development of the cadastral component of its NSDI through a wide range of partnerships between public bodies and those between a public body and a private corporation $[\mathbf{1 8}, \mathbf{3 1}]$. Some are successful and some are not, but all are useful in understanding how partnerships can be better utilised in cadastral and NSDI development. The issues involved in establishing partnerships include standards, cost sharing, privacy, copyright and inter-state/inter-person rivalry. However, the Australian experience also suggests that where there is a need, there is always a solution. It is expected that the determining factors in an on-going research project into partnerships in SDI development will be the type of partnership, the objective, the business driver, organisation settings of the partners and leadership by visionary managers.

\section{National Cadastral Infrastructures}

A move to create national cadastral systems in countries which are federations of states, provinces or territories (such as Germany, USA, Canada, Russia, Peoples Republic of China, Malaysia, Argentina, Brazil, Australia) raises many issues. However it is a very important development which has major national economic and environmental benefits. Users are wanting national medium or large scale spatial data sets, particularly based on the cadastral layer. The example of the development of the Public Sector Mapping Agencies (PSMA) national data set in Australia, based primarily on state and territory digital cadastral data bases (DCDB), together with the commitment to a national competition policy, has raised the concept of national cadastral data sets [18]. These national data sets are being used by national utilities such as the telecommunications agencies, electoral boundaries, census, the transport industry, defence and natural resource management agencies, to name some key users. Such national cadastral data sets are key components of any future national land administration infrastructure. However it must be remembered that each state is responsible under the Australian Constitution for land and land administration, like many other countries which are federations, which results in each state and territory having slightly different land administration and cadastral systems.

One of the differences between the Australian jurisdictions is that different states define parcel boundaries differently. In some states cadastral boundaries can move while in others they cannot. The result is that the concept of a land parcel in the different Australian jurisdictions is slightly different. The major difference is that some jurisdictions permit adverse possession as to part of a parcel and some do not (this means in some jurisdictions a boundary may have moved and is not shown on the digital cadastral map). This difference can also significantly affect the operation of the local land market. 
At one level it can be stated in Australia that while all the states permit adverse possession and the two Territories do not, the differing requirements within each state's own scheme must be recognised. For example the State of South Australia only permits adverse possession where registered land has been abandoned or perhaps informally transferred by the registered proprietor, and the registered proprietor does not object to the proposed registration of the occupier as the new registered proprietor. If a focus is taken on adverse possession of part of a parcel, a situation which can affect the location of the boundary between adjoining parcels, a different conclusion may result. While the State of New South Wales permits adverse possession it does not allow adverse possession of less than a whole parcel. The State of Victoria on the other hand does, which is in line with traditional adverse possession of land not within the Torrens registration scheme $[\mathbf{1 9}, \mathbf{2 0}, \mathbf{2 1}]$.

A single national cadastre in Australia is technically possible as illustrated by the PSMA mapping base [18] mentioned previously. The positive response from the spatial information industry towards such a product has been favourable, suggesting that a single national cadastre is also desirable. However a possible difficulty is the different approach of each jurisdiction to adverse possession of registered title land, and particularly to part parcel. If Australia decides to adopt common cadastral legislation, it appears that this "possible difficulty" could prove to be a stumbling block in moving towards a national cadastral system. Again this highlights the importance of a broader and more national view in undertaking the re-engineering of State and Territory land administration systems. In the past such changes were only ever considered within a single jurisdictional focus, however that parochial view may require modification.

The spatial hierarchy problem

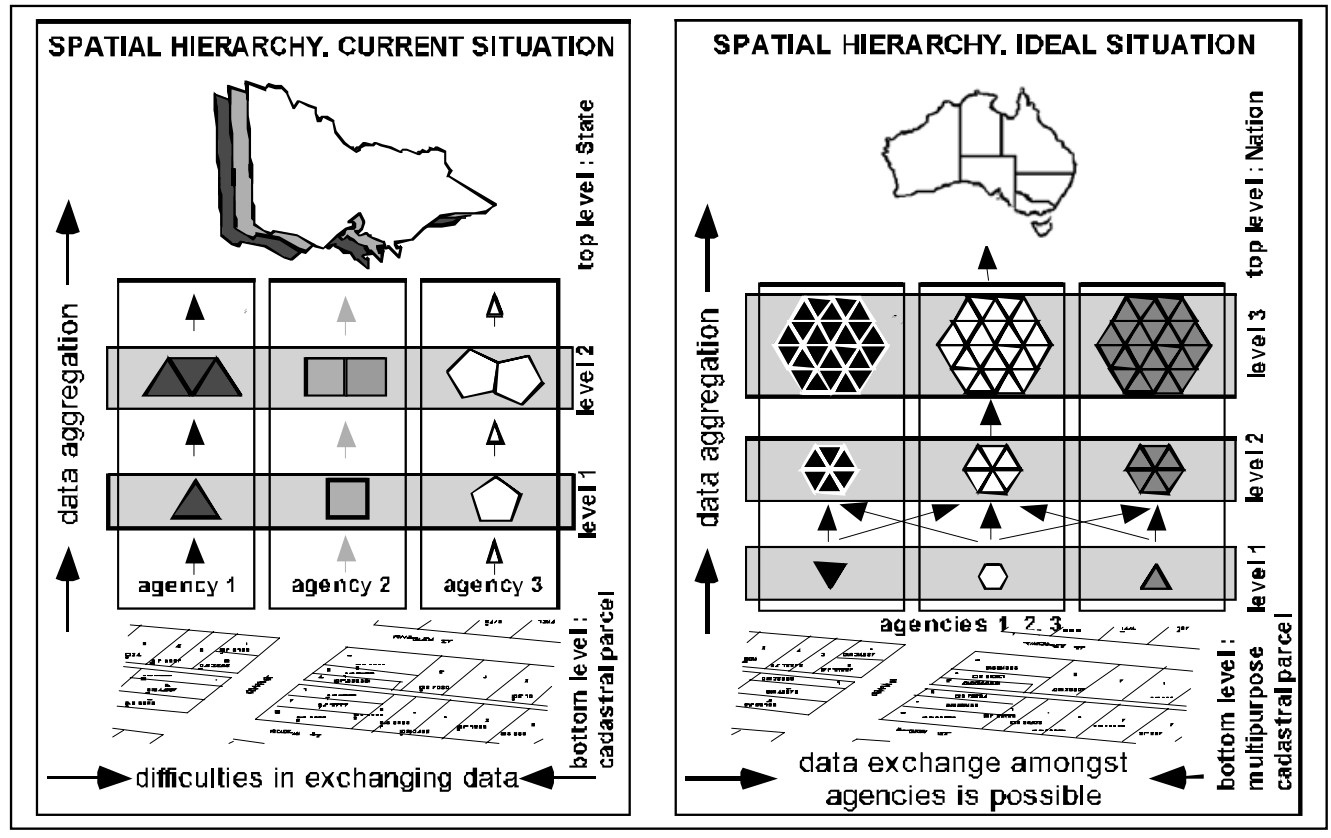


With the advent of spatial business systems demanding more from spatial data infrastructures and the broader land administration and cadastral systems, particularly regarding land related information, problems with the "spatial hierarchy" are becoming an issue. The spatial hierarchy problem refers to the difficulties in exchanging, aggregating and analysing different data sets based on non-coterminous boundaries, as illustrated in Figures 6 and 7 [9].

Figure 6 illustrates the current situation where each agency collects and aggregates data based on its own hierarchically structured boundaries. The bottom layer is the land parcel or cadastral map, a core component of a land administration infrastructure. Land parcels are recognised as indivisible units. This is common practice in most countries. As a result, data aggregation is possible within each agency but presents difficulties to the sharing of data between various agencies.

Research is being undertaken to examine trends in such organisations as the Australian Bureau of Statistics (ABS), health and social security departments, and Australia Post to explore the use of Hierarchical Spatial Reasoning (HSR) in assisting in the spatial hierarchy problem. Such an approach has been applied in different applications such as "way finding" for navigation systems [3]. The properties inherent in HSR theory make it suitable as the base for a re-organisation of spatial units under a common hierarchy. This research aims to apply the principles of HSR theory to the re-organisation of spatial boundaries. Figure 7 shows a model where all agencies share a common structure that enables better analyses using different data sets. By applying HSR to this problem, GIS will hopefully improve its capacity for data integration (one of the items on the agenda of GIS institutions such as the National Center for Geographic Information and Analysis (NCGIA) and the University Consortium for Geographic Information Science (UCGIS)).

Recognising that land administration systems are now providing an infrastructure for a much wider range of uses and particularly the provision of land related information, any reengineering of such systems should take the spatial hierarchy problem into account.

Integration of customary and traditional tenures into "western" land administration systems

The inclusion of indigenous interests in land has been recognised by the United Nations in Agenda 21 as important for maintaining and developing a land information system in support of sustainable development. This is a world trend with indigenous interests in land having been recognised and integrated to some degree within mainstream land administration systems, such as those in New Zealand, USA, Fiji, Papua New Guinea, in many parts of Africa and more notably the establishment of the Nunavut Territory in Canada by the Inuit people.

On the one hand the integration of diverse land tenures into one comprehensive land administration system is essential and inevitable, however it presents many difficulties which have been highlighted around the world. On the other hand the new spatial information technologies and the emerging multi-purpose cadastral systems offer much potential in assisting in solving the inevitable problems in developing the land administration infrastructures in jurisdictions which have to address this issue, will need over the next 10 years. See for example Ezigbalike et al [59], Jayanadan and Williamson [60], Rakai et al [61], Rakai and Williamson [62, 63], Iatau and Williamson [64], Grant [65]. 
From an Australian perspective for example, the recent results from the High Court's decision concerning Mabo and Wik, and the inception and implementation of the Native Title Act 1993 highlight the issue. These decisions are driving the integration of two vastly different land tenure systems in Australia, namely traditional Aboriginal land tenure and the Australian Torrens system. The amalgamation must result in future modern multi-purpose cadastres in Australia being able to include native title interests while maintaining cultural integrity [2]. The tensions inherent in amalgamating two different land tenure systems such as these present a challenge to any country in this situation which is embarking on land administration reform. A major issue is that western authorities have an assumed cartographic knowledge which is not shared by the indigenous groups. This is a major obstacle which needs to be addressed in future land administration systems.

\section{Understanding the complexity of cadastral systems and the maintenance of the spatial component}

The cadastral system has two components: textual and spatial. Both are core components of any land administration infrastructure. The spatial component consists of cadastral maps, the geodetic framework and survey plans. Maintenance of this spatial component involves updating and upgrading of the 'proposed', 'current legal' and 'as built' spatial data layers of land subdivision activities through various means including the Internet [10, 11, 22, 23, 67] as illustrated in Figure 8. In one sense this diagram shows the cadastral data flows associated with subdividing or consolidating land parcels in a country or provincial or county land administration system. The goal of the maintenance exercise is to provide a homogeneous statewide coverage of cadastral data with minimum maintenance duplication. As shown in Figure 8 , the objective is not just a matter of updating the state digital cadastral map (often called a digital cadastral data base or DCDB) but of providing an updated digital environment for the effective functioning of the cadastral system.

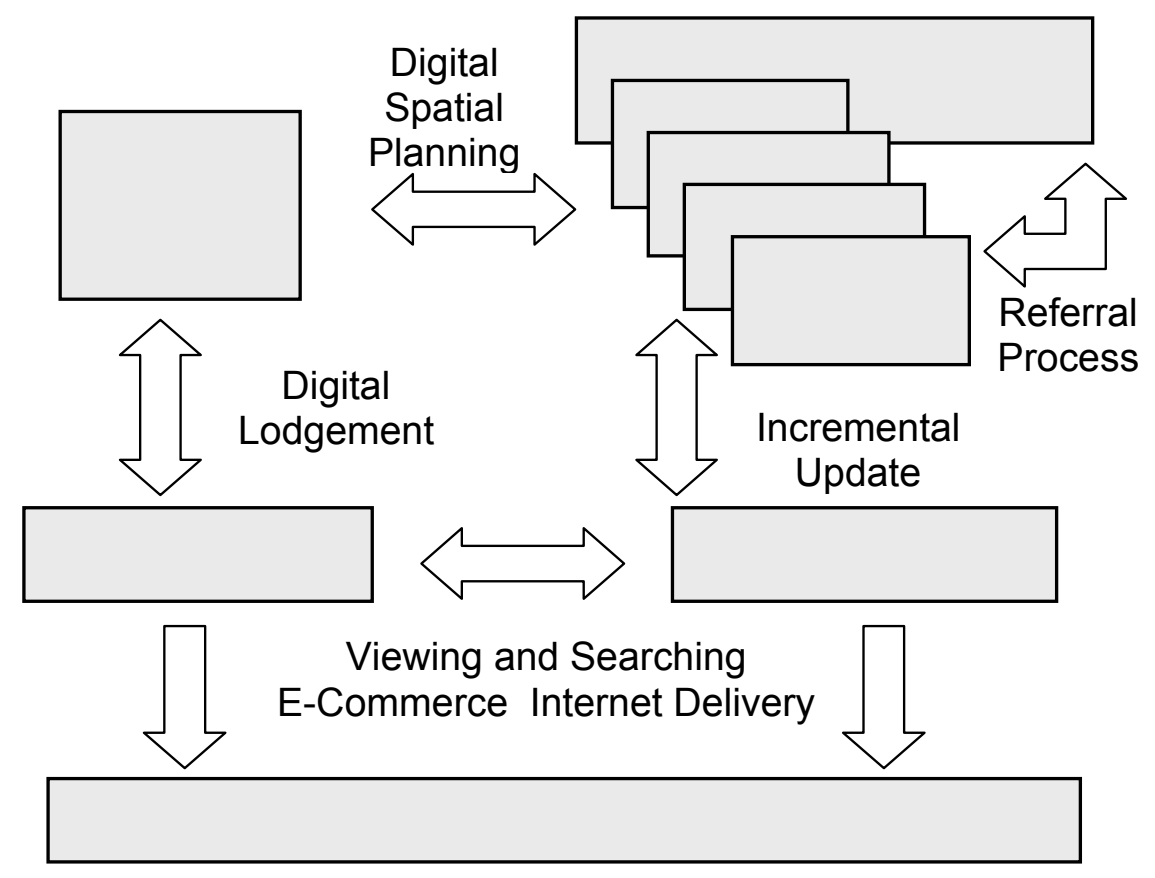

Figure 8. Complexity of Cadastral Systems 
This digital view of the spatial component of the cadastre in particular reinforces the need for an integrated view when re-engineering land administration and cadastral systems, and highlights the complexity and inter-dependence of all the components and partners in a spatial data infrastructure.

\section{Impact of the $W W W$ and communications technologies}

The WWW and communication technologies are having a major impact on the operation of land administration and cadastral systems. The use of GIS in land administration over the years, in both the natural resources and parcel based areas, has resulted in the proliferation of many large distributed spatial databases. Such spatial databases require efficient means of data management and access tools that intelligently guide users to the data. The work of the Open GIS Consortium has has a major impact on these developments [55]. Metadata (data about data) and metadata engines are examples of intelligent spatial access tools, areas where there is considerable research being undertaken. Metadata provides users with information about the data prior to retrieving and using the data. A Metadata engine can use the metadata for searching and retrieving datasets from across the WWW [22]. The WWW is also often viewed as storage banks where spatial information can be stored and retrieved locally by Internet users. A prototype developed by Polley uses Java and the Computer Gateway Interface (CGI) language to facilitate a two-way flow of spatial data through the WWW [24].

The WWW is now seen as an alternative to delivering cadastral information from public bodies to the public. In fact some land administration organisations are seeing their whole delivery strategy based on the WWW. WWW servers and the emergence of Map Servers also facilitate the move towards the realisation of the multi-purpose cadastre concept described over 20 years ago and more recently in the Bogor Declaration on Cadastral Reform and Cadastre 2014. However it is only now, due to the technology, that the vision is becoming a reality.

Together with distributed databases, the WWW and Map Servers, a multi-purpose cadastre is expected to allow government agencies to overlay cadastral maps, title registers, planning and other vital land resources live and interactively in order to show the complete legal situation of the land to Internet users across the world [16]. In other words it is becoming possible to identify all rights, restrictions and responsibilities relating to land over the WWW. No doubt the WWW, together with advanced communication and information technologies such as the Wireless Application Protocol (WAP), will continue to be the drivers for the future development of land administration infrastructures.

\section{Evolving government institutions}

Land administration and cadastral systems have continued to undergo re-engineering over the last 20 years in many developed countries and particularly during the last decade. As a result of the economic reform driver, many governments are moving away from service delivery to focus on directing and setting policy in the land administration and spatial information environment. This is resulting in the growth of a vibrant spatial information industry in some countries.

At the same time as governments recognise the importance of land administration to sustainable development, government institutions have continued to evolve. A trend has been the amalgamation of all the land related information organisations into one department, group 
or unit. A good example is Land Victoria in the Government of Victoria, Australia, but examples can be found world-wide [58].

An important development has been the emphasis in spatial information development at a national level in countries like Australia which are federations of states. In the past the only organisation with the ability to provide national spatial data was the Australian Federal Government. However as a result of its mandate, the Federal Government tended to focus on small-scale spatial data (1:100,000 scale and less). With the growth of medium and largescale digital data $(1: 2-25,000)$ at a state and territory level in Australia, usually based on the cadastre, users are demanding access to this data as an aggregated product at a national level. This has seen the growth of the previously mentioned Public Sector Mapping Agencies (PSMA) [18], as an excellent example of the partnership concept in Australia, to provide these products.

Another outcome of these changing institutions has been a growing partnership between academic institutions and both government and the private sectors. With universities also having been significantly affected by micro-economic reform policies resulting in reduced government funding, universities are now providing much of the research and development to government in the broad land administration, cadastral and spatial data infrastructure areas, research which was previously undertaken in-house by government.

As land administration systems take on a more multi-purpose role the necessity for more integrated government institutions and stronger partnerships will increase.

\section{Education and Professional structures}

The land administration and spatial information revolution has influenced related education and professional structures in countries such as Australia and Canada over the last decade or so. These influences and resulting trends are relevant considerations when developing new land administration and cadastral systems. Professions such as surveying continue to evolve to accommodate the spatial information revolution, while endeavoring to maintain traditional services.

At the university level the impact on surveying has been significant. The surveying discipline has been transformed over the last decade. We have seen the adoption in Australia and internationally of the geomatics concept where the focus of the discipline is to design, build and manage the spatial dimension of the natural and built environment. Several programs like those at the Universities of Melbourne and New South Wales in Australia have become accredited engineering degrees. Other programs have moved down the spatial sciences or geoinformation path.

At a professional level there have been ongoing discussions in several countries for an amalgamation of the spatial professions into one spatial information body.

An interesting development in Australia is the joint creation of a National Spatial Accreditation Authority by the spatial information industry and professional bodies. This is being coordinated by The Institution of Surveyors, Australia Inc. Such a move is considered essential in a de-regulated environment where traditional bodies like State and Territory Boards of Surveyors in Australia have come under threat as a result of a national competition 
policy. At the same time as these developments are occurring, the whole question of the statutory control of spatial data is under review.

These issues should be considered when undertaking reform of land administration and cadastral systems.

Benchmarking or how does a government know if it has a good land administration system?

As governments are becoming more cost conscious and as management practices such as quality assurance and international best practice are impacting on all government services, governments are questioning the efficiency of their land administration and cadastral systems to a greater extent. Simply put, how does a government or jurisdiction know if it has an efficient and effective land administration and cadastral system?

As a result of these trends, there is ongoing research into the approaches and techniques in evaluating the success of these systems. On the one level there has been a lot of work in developing guidelines as to what constitutes a good system or what are the components of a good system. This has included the FIG Statement on the Cadastre, the UNECE MOLA Land Administration Guidelines, the Bogor Declaration on Cadastral Reform and the FIG Cadastre 2014 vision as examples (also see [36, 58]). However none of these documents provided advice on how to evaluate the performance of a system.

While there is still no definitive approach to evaluating land administration and cadastral systems, there has been some work undertaken which is useful.

The first is the work by Commission 7 of the FIG which is responsible for cadastre and land management. Over the period 1994-98 the Commission undertook an international benchmarking exercise of 53 countries or jurisdictions world wide [26]. This approach was adopted as the best way to evaluate the performance of cadastral systems. The study collected economic and statistical indicators about the size, activity and efficiency of each cadastral system so that an attempt could be made to crudely standardise the data so that it could be compared. The four-year exercise proved to be problematic since it was difficult to standardise many of the definitions and processes. However after much effort, international goodwill and collaboration, some useful data was produced which is still proving of benefit to countries and jurisdictions for evaluating and improving their systems.

Another approach has been explored by Williamson and Fourie [32] where they adopted rigorous case study methodologies from the social sciences to cadastral reform. Again while this approach does not specifically provide an approach to determining the performance of systems, it does provide a structured approach to evaluating cadastral systems.

Finally the work of Dale $[\mathbf{8 , 7 0 ]}$ on developing a process to determine the performance of land markets in countries undergoing transition in Eastern and Central Europe is also useful. He has developed a land market model incorporating policy, legal and financial components. Within this framework a qualitative scoring system is applied, with the ability to normalise the results. The result is a process to compare the development or efficiency of a land administration or cadastral system from one country to another. 
This paper has attempted to look at the issues in re-engineering land administration and cadastral systems to better meet future needs. The need for a vision which incorporates sustainable development objectives and is based on a broader and more integrated approach is argued. In order for countries or jurisdictions to work towards such a vision a model for reengineering land administration systems is proposed. The components of the framework are used to review issues and strategies based on the experience of the authors and their colleagues.

In discussing land administration and cadastral reform the paper has described the process leading to the Bathurst Workshop and Melbourne Conference on land tenure and cadastral infrastructures to support sustainable development, which resulted in the Bathurst Declaration. It outlines previous work by many organisations and individuals which was used as a basis for the workshop and conference, and which contributed to the Declaration.

The implementation issues outlined in this paper have tried to highlight the complexity and inter-dependency of issues in land administration, cadastral systems and spatial information management. They also highlight their multi-disciplinary nature. The paper has endeavoured to show that any land administration strategy at any level of government must take a broader approach than in the past by recognising a wide range of social, economic and land related issues. A key outcome of such strategies is the development of land administration infrastructures and spatial information management strategies.

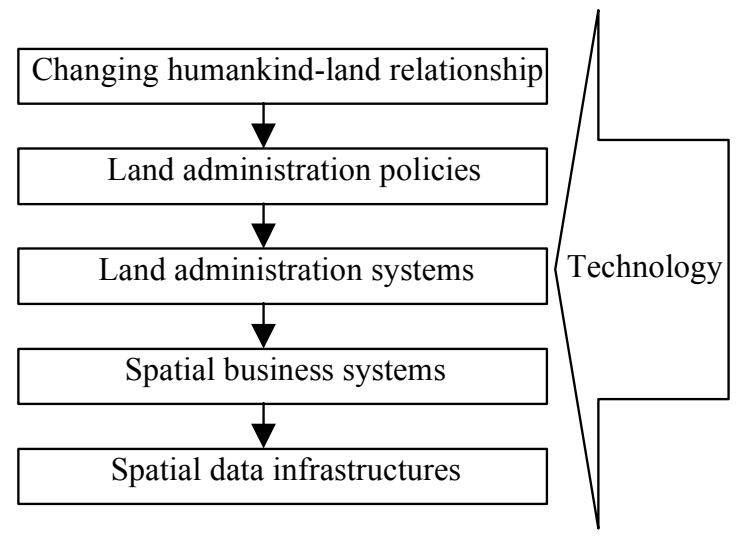

Figure 9. Developing spatial information management strategies

The development of these spatial information management strategies requires an understanding of the relationship between the changing humankind-land relationship, land administration policies, land administration systems, spatial business systems and spatial data infrastructures, while recognising the impact of technology across these dimensions (Figure 9). In this context, spatial data infrastructures will evolve to accommodate the business needs of land administration decision support systems and multi-purpose cadastres. An emphasis on business needs as distinct from infrastructure needs of spatial information will see a reengineering of current SDIs as key components of future land administration systems.

In summary, sustainable development will be the focus for the changing humankind-land relationship in the foreseeable future. This will demand sophisticated land administration infrastructures in order to support the necessary decision-making. These in turn will require support from more generic information technologies integrated with spatial information technologies that can process and package data that is of sufficient quality, accuracy, relevance and inter-operability to the decision-makers. Herein lies the challenge that needs to be tackled in developing the next generation of land administration systems.

\section{ACKNOWLDEGEMENTS}


The authors acknowledge that this paper is a substantially revised version of a paper presented at the United Nations-International Federation of Surveyors International Conference on Land Tenure and Cadastral Infrastructures for Sustainable Development held in Melbourne, Australia 24-27 October, 1999

$<$ http://www.geom.unimelb.edu.au/UNConf99/>. The authors also gratefully acknowledge the support of Land Victoria (LV) of the Victorian Government, the Land Information Centre (LIC) of the New South Wales Government, the Australian Surveying and Land Information Group (AUSLIG) of the Commonwealth Government and the Australian Research Council (ARC) (Grants C19700324 and C49930403) in supporting the research mentioned in the paper. The authors also acknowledge the assistance provided by their colleagues at the Department of Geomatics, the University of Melbourne in the preparation of the paper

http://www.geom.unimelb.edu.au/research/SDI_research/. However, the views expressed in the paper are those of the authors and do not necessarily reflect the views of LV, LIC, AUSLIG or ARC.

\section{REFERENCES}

1. AUSLIG, (1999) Webpage on Australian Spatial Data Infrastructure Partnerships Program. Accessed 1 July 1999. <http://www.auslig.gov.au/pipc/asdi/part.htm>.

2. Brazenor, C., Ogleby, C.L. and Williamson, I.P. (1999) The Spatial Dimension of Aboriginal Land Tenure. Presented at $6^{\text {th }}$ South East Asian Surveyors Congress, Fremantle, 1-6 November 1999.

3. Car, A., (1997) Hierarchical Spatial Reasoning: Theoretical Consideration and its Application to Modeling Wayfinding. PhD thesis, Technical University, Vienna.

4. Chan, T. O., (1998) The Dynamics of Diffusion of Corporate GIS. PhD thesis, The University of Melbourne.

5. Chan, T. O. and Williamson, I. P., (1996) A model of the decision process for GIS adoption and diffusion in a government environment. In Proceedings of URISA '96, (Utah: URISA) pp. 247-260.

6. Chan, T. O. and Williamson, I. P., (1999a) The different identities of GIS and GIS diffusion. International Journal of Geographical Information Science, 13(3), 267-281.

7. Chan, T. O., and Williamson, I. P. (1999b) Spatial data infrastructure management: lessons from corporate GIS development. Paper presented at AURISA 99, Blue Mountain, NSW, 22-26 November, 10 pages.

8. Dale, P.F. (1999) Cadastral and land administration systems in countries in transition. Lecture to the Department of Geomatics, University of Melbourne. Accessed 27 August, 1999 $<$ http://sunspot.sli.unimelb.edu.au/subjects/451/418/lecture10PPT/ppframe.htm>

9. Eagleson, S., Escobar, F., and Williamson, I. P., (1999) Spatial Hierarchical Reasoning Applied to Administration Boundary Design Using GIS. Presented at $6^{\text {th }}$ South East Asian Surveyors Congress, Fremantle, 1-6 November 1999.

10. Effenberg, W. W., Enemark, S. and Williamson, I. P. (1999) Framework for Discussion of Digital Spatial Data Flow within Cadastral Systems. The Australian Surveyor, 44(1), 35-43.

11. Falzon, K. and Williamson, I. P. (1998) Digital Lodgement of Cadastral Survey Data in Victoria. Proceedings of the 39th Australian Surveyors Congress, Launceston, Tasmania, 8-13 November 1998, 339355.

12. Federal Geographic Data Committee (1997) A Strategy for the NSDI. Federal Geographic Data Committee, Reston, VA, 25 March, $1999<$ http://www.fgdc.gov/nsdi/strategy/strategy.html>.

13. FIG (1995) Statement on the Cadastre. International Federation of Surveyors. WWW accessed 5th September, $1999<\mathrm{http}$ //www.fig7.org.uk/cadastre/statement_on_cadastre.html>

14. Kaufmann, J. (1998) 'Cadastre 2014' - Report of Commission 7 Working Group 7.1, Modern Cadastres. Congress Proceedings, Commission 7, FIG XXI FIG Congress, Brighton 1998. WWW accessed 5th September, $1999<$ http://www.fig7.org.uk/Brighton98/proceedings.html>

15. Kaufmann, J. and Steudler, D. (1998) Cadastre 2014: A Vision for a Future Cadastral System (Rheinfall, Switzerland: FIG). WWW accessed 5th September, $1999<$ http://www.swisstopo.ch/figwg71/Docs/Cad2014index.htm>

16. Majid, S. and Williamson, I. P. (1999) Cadastral Systems on the World Wide Web - A Multi-Purpose Vision. Presented at AURISA 99, Blue Mountain, NSW, 22-26 November, 9 pages. 
17. MOLA (1999) Land Administration Guidelines. Meeting of Officials on Land Administration, UN Economic Commission for Europe. ECE/HBP/96 Sales No. E.96.II.E.7, ISBN 92-1-116644-6. WWW accessed 5th September, 1999 < http://www.sigov.si/mola/Preview/html/projects.html\#nas1>

18. Mooney, J. D. and Grant, D. M. (1997) The Australian Spatial Data Infrastructure. In Framework of the World, edited by D. Rhind. (Cambridge: GeoInformation International), pp. 187-201.

19. Park, M., Ting, L. and Williamson, I.P. (1998) Adverse possession of Torrens land. 72(11) Law Institute Journal 77 (Victoria, Australia).

20. Park, M. and Williamson, I.P. (1999a) Australian cadastres: the role of adverse possession of part parcels. The Australian Surveyor 4(2), 151-158 (1999).

21. Park, M. and Williamson, I.P. (1999b) The effect of adverse possession to part on a future Australian cadastre. Presented at 6th South East Asian Surveyors Congress, Fremantle, 1-6 November 1999, 143-151.

22. Phillips, A., Williamson, I. P., and Ezigbalike, I. C. (1998) The Importance of Metadata Engines in Spatial Data Infrastructures. Proceedings of AURISA '98, Perth, Western Australia, 23-27 November 1998.

23. Polley, I., Williamson, I. P., and Effenberg, W. W. (1997) Suitability of Internet Technologies for Access, Transmission and Updating Digital Cadastral Databases on the Web. Proceedings of AURISA 97, Christchurch, New Zealand, 17-21 November 1997

24. Polley, I. and Williamson, I.P. Facilitating Digital Data Transactions Using an On-line Tool. Geomatica, 53(4), 415-425 (1999).

25. Rajabifard, A., Chan, T. O., and Williamson, I. P. (1999) The Nature of Regional Spatial Data Infrastructures. Paper presented at AURISA 99, Blue Mountain, NSW, 22-26 November, 10 pages.

26. Steudler, D., Williamson, I.P., Kaufmann, J. and Grant D.M. (1997) Benchmarking Cadastral Systems. The Australian Surveyor, 42(3), 87-106

27. Ting, L. and Williamson, I.P. (1999). Land administration and cadastral trends: the impact of the changing humankind-land relationship and global drivers. Proceedings of the joint United Nations and FIG International Conference on Land Tenure and Cadastral Infrastructures for Sustainable Development, Melbourne, 24-27 October, 1999, 252-275. <http://www.geom.unimelb.edu.au/UNConf99/>

28. Ting, L. and Williamson, I., (1999) Cadastral Trends: A Synthesis. The Australian Surveyor, 4(1), 46-54.

29. UN/FIG (1996) Bogor Declaration on Cadastral Reform. FIG Webpage accessed on July 301999. $<$ http://www.sli.unimelb.edu.au/fig7/Bogor/BogorDeclaration.html $>$

30. UN (1997). Report of Meeting of the Ad hoc Group of Experts on Legislation for Surveying and Mapping, New York, U.S.A., 6 June, 1997. UN reference DDSMS/SEM.97/2.

31. Williamson, I. P., Chan, T. O., and Effenberg, W. W. (1998) Development of spatial data infrastructures lessons learned from the Australian digital cadastral databases. Geomatica, 52(2), 177-187.

32. Williamson, I.P. and Fourie, C. (1998). Using the Case Study Methodology for Cadastral Reform. Geomatica, 52(3), 283-295.

33. Williamson, I.P., (1996) A Land Information Vision for Victoria, Report for Geographic Policy and Coordination, Victoria, 21p. WWW accessed on August 221999. http://www.sli.unimelb.edu.au/research/publications/IPW publ.html

34. UN-FIG Bathurst Declaration on Land Administration for Sustainable Development 1999: http://www.sli.unimelb.edu.au/UNConf99/proceedings.htm

35. UN, (1992) Agenda 21.United Nations Division for Sustainable Development. 15 June, $<\mathrm{http}$ ://www.un.org/esa/sustdev/agenda21 text.htm>.

36. Williamson, I.P. 2000. Best Practices for Land Administration Systems in Developing Countries. International Conference on Land Policy Reform, Jakarta 25-27 July, 2000 http://www.landpolicy.org/conference/index.htm Accessed 8 August, 2000.

37. Polley, I. and Williamson, I.P. GIS, the Internet and the Cadastre: Coming Together. The Australian Surveyor, 44(2), 183-188 (1999) 
38. Binns, Sir Bernard O. and Dale P.F. 1995. Cadastral surveys and records of rights in land. Based on the 1953 study by Sir Bernard o. Binns, revised by Peter F. Dale. FAO Land Tenure Studies 1, UNFAO Rome. http://www.fao.org/icatalog/book_review/giii/land1-e.htm accessed 7 August, 2000.

39. Dowson, E. and V.L.O. Sheppard 1956. Land Registration. HMSO, London.

40. Simpson, S. R. 1976. Land Law and Registration. Cambridge University. Press, Cambridge

41. United Nations 1973. Report of the Ad Hoc Group of Experts on Cadastral Surveying and Mapping. New York.

42. United Nations 1985. Conventional and Digital Cadastral Mapping. Report of the Meeting of the Ad Hoc Group of experts on Cadastral Surveying and Land Information Systems. Economic and Social Council E/CONF.77/L.1.

43. Larsson, Gerhard 1991. Land Registration and Cadastral Systems. New York: Longman Scientific and Technical.

44. Dale, P.F., 1976. Cadastral Surveys within the Commonwealth. HMSO, London.

45. Land Tenure Centre, 2000. University of Wisconsin-Madison. http://www.wisc.edu/ltc/ Accessed 7 August, 2000

46. UN, 1997. Proceedings of Meeting of the Ad Hoc Group of Experts on legislation for Surveying and Mapping, $6^{\text {th }}$ United Nations Regional Cartographic Conference for the Americas, New York, 6 June, 1997.

47. Dale, R.F. and J.D. McLaughlin, 1988. Land Information Management. Clarendon Press, Oxford.

48. Dale, P.F. and McLaughlin, J.D., 1999. Land Administration. Oxford University Press, 169p.

49. Holstein, L. 1996. Towards best practice from World Bank Experience in Land Titling and Registration. International Conference on Land Tenure and Administration, Orlando Florida, November, 1996, 22p.

50. Feder,G. and D.Feeney. 1991. Land tenure and property rights: Theory and Implications for Development Policy. The World Bank Economic Review. 5(1).

51. Byamugisha, F.K. 1999. The Effects of Land Registration on Financial Development and Economic Growth: A Theoretical and Conceptual Framework. Policy Research Working Paper No. 2240. (November 1999).

52. Deininger, K. and H.Binswanger, 1999. The evolution of the World Bank's Land Policy: Principles, Experience, and Future Challenges. The World Bank Research Observer 14(2) (August, 1999), $247-76$.

53. Williamson, I.P., Ting, L. and D.M.Grant, 1999. The evolving role of land administration in support of sustainable development. The Australian Surveyor 44(20), 126-135.

54. McKean, M.A. 2000. Siting and designing successful institutions for community rights in natural resources. International Conference on Land Policy Reform, Jakarta 25-27 July, 2000 http://www.landpolicy.org/conference/index.htm Accessed 8 August, 2000.

55. Open GIS Consortium, 2000, The Open GIS Guide, Accessed: 27th January 2000, http://www.opengis.org.

56. McAuslan, J.P. The global imperative of land reform: the legal and institutional element. International Conference on Land Policy Reform, Jakarta 25-27 July, 2000

http://www.landpolicy.org/conference/index.htm Accessed 8 August, 2000.

57. Rajabifard, A., Chan, T.O. and I.P.Williamson. 1999. The nature of Regional Spatial Data Infrastructures. Proceedings of AURISA'99, Blue Mountains, New South Wales, Australia, 22-26 November, 1999 (CD ROM).

58. Williamson, I.P. 2000. Institutional Framework Reforms for Land administration. Topic Cycle 10, World Bank land administration Project - Part C. National Development Planning Agency (BAPPENAS) and National Land Agency, Government of the Republic of Indonesia. www.landpolicy.org Accessed 9 August, 2000 .

59. Ezigbalike, I., Rakai, M.E.T. and Williamson, I.P. Cultural Issues in Land Information Systems. Position paper commissioned by the UN Food and Agriculture Organisation, Rome (26p) (1995).

60. Jeyanandan D., and Williamson, I.P. A Cadastral Model for Developing Countries. Proceedings of National Conference on Cadastral Reform '90, Melbourne, Victoria, 81-93 (1990). 
61. Rakai, M.E.T., Ezigbalike, I.C. and Williamson, I.P. Traditional Land Tenure Issues for LIS in Fiji. Survey Review 33(258) 247-262 (1995).

62. Rakai, M.E.T. and Williamson, I.P. Implementing LIS/GIS from a Customary Land Tenure Perspective The Fiji Experience. The Australian Surveyor 40(2) 112-121 (1995a).

63. Rakai, M.E.T. and Williamson, I.P. Implications of incorporating customary land tenure data into a land information system. Trans Tasman Surveyor 1(1) 29-38 (1995b).

64. Iatau, M.D. and Williamson, I.P. Using the Case Study Methodology to Review Cadastral Reform in Papua New Guinea. The Australian Surveyor, 42(4) 157-165 (1997).

65. Grant, C. 1998. When Titling meets tradition. . Proceedings of the $39^{\text {th }}$ Australian Surveyors Congress, 8-13 November, 1998, Launceston, Tasmania, Australia http://sunspot.sli.unimelb.edu.au/...ts/451/418/lecture6/Tradition.html

66. Schedu, M., Effenberg, W.W. and Williamson, I.P. Incremental update and upgrade of Spatial Data. Zeitschrift fur Vermessungswesen. 125(4) 115-120 (2000).

67. Polley, I. and Williamson, I.P. GIS, the Internet and the Cadastre: Coming Together. The Australian Surveyor, 44(2) 183-188 (1999).

68. Panel on a Multipurpose Cadastre, 1983, Procedures and Standards for a Multipurpose Cadastre: Washington D.C, National Academy Press.

69. Eagleson, S., Escobar, F. and Williamson I.P. 2000. Hierarchical Spatial Reasoning applied to the Automated Design of Administrative Boundaries using GIS. Proceedings of the URISA 2000 Conference, Orlando, USA 19-23 August, 2000 (This paper won the URISA Student Horwood Award).

70. Dale, P.F.and Baldwin, R. 1999. Emerging land markets in Central and Eastern Europe. Proceedings of the Second World Bank/FAO Workshop on Lessons for EU Accession, Warsaw, Poland, June 27-29, 1999. Edited by C.Csaki and Z.Lerman. World Bank Technical Paper No. 465, 81-109.

NOTE: Most of the articles involving the authors are available at http://www.sli.unimelb.edu.au/research/publications/IPW publ.html. 


\section{University Library}

\section{- M M N E R VA A gateway to Melbourne's research publications}

Minerva Access is the Institutional Repository of The University of Melbourne

Author/s:

Williamson, Ian P.;TING, LISA

Title:

Land administration and cadastral trends: a framework for re-engineering

Date:

2001

Citation:

Williamson, I. P., \& Ting, L. (2001). Land administration and cadastral trends: a framework for re-engineering. Computers, Environment and Urban Systems, 25, 339-366.

Publication Status:

Published

Persistent Link:

http://hdl.handle.net/11343/33983 